\title{
Memória e testemunho da violência contra o pensamento de Paulo Freire a partir de "A visita do inspetor-geral", de Bernardo Kucinski
}

\author{
Memory and testimony of violence against Paulo Freire's thought in \\ "A visita do inspetor-geral", by Bernardo Kucinski
}

\section{Memoria y testimonio de la violencia contra el pensamiento de Paulo Freire en "A visita do inspetor-geral", de Bernardo Kucinski}

Nelson Martinelli Filho I

https://orcid.org/0000-0002-6956-5400

Thaís Bedendo 2

https://orcid.org/0000-000 I-8454-7262

\begin{abstract}
Resumo: Este trabalho analisa o atual contexto de perseguição à obra e ao pensamento de Paulo Freire por meio da leitura crítica de "A visita do inspetor-geral", conto de Você vai voltar pra mim e outros contos, de Bernardo Kucinski (2014), com foco na repetição das estratégias de censura e de violência contra determinados vieses políticos e ideológicos na história recente do Brasil. Para a fundamentar a discussão, no plano teórico, realizouse um levantamento bibliográfico dos autores Paul Ricoeur (2007) e Jeanne Marie Gagnebin (2006) sobre memória, de Márcio Seligmann-Silva (2003/2005) e Jaime Ginzburg (20II) sobre literatura de testemunho, e de Bruno Botelho Costa (2016), Carlos Rodrigues Brandão (2006) e Moacir Gadotti (1996), entre outros, que abordam a obra de Paulo Freire. Observou-se, dessa forma, que a narrativa de Kucinski atua como um testemunho do autoritarismo da ditadura, de modo que seu livro se torna documento de memória na contramão das vias institucionalizas que operam o silenciamento e a manipulação do passado.
\end{abstract}

Palavras-chave: Paulo Freire. Bernardo Kucinski. Testemunho.

Abstract: This article analyzes the current context of the persecution of Paulo Freire's work and thought through a critical reading of "A visita do inspetor-geral", a short story from Você vai voltar pra mim e outros contos, Bernardo Kucinski (2014), with focus on the repetition of censorship and violence strategies against certain political and ideological biases in the recent history of Brazil. To support the discussion, at the theoretical level, a bibliographic survey of the authors Paul Ricoeur (2007) and Jeanne Marie Gagnebin (2006) on memory was

\footnotetext{
' Doutor em Letras. Professor do Programa de Pós-Graduação em Letras da Universidade Federal do Espírito Santo (PPGL/UFES); Professor do Programa de Mestrado Profissional em Letras (PROFLETRAS/Ifes); Professor do Programa de Pós-Graduação em Ensino de Humanidades do Instituto Federal do Espírito Santo (PPGEH/lfes). Instituto Federal do Espírito Santo. nelsonmfilho@gmail.com

${ }^{2}$ Mestranda do Programa de Pós-Graduação em Ensino de Humanidades do Instituto Federal do Espírito Santo (PPGEH/lfes). tbedendo@gmail.com
}

Olhar de professor, Ponta Grossa, v. 24, p. I-22, e-16757.014, 2021.

Disponível em <https://revistas2.uepg.br/index.php/olhardeprofessor> 
carried out, by Márcio Seligmann-Silva (2003/2005) and Jaime Ginzburg (201I) on testimonial literature, and Bruno Botelho Costa (2016), Carlos Rodrigues Brandão (2006) and Moacir Gadotti (1996), among others, who approach the work of Paulo Freire. In this way, it was observed that Kucinski's narrative acts as a testament to the authoritarianism of the dictatorship, so that his book becomes a document of memory against the institutional paths that operate the silencing and manipulation of the past.

Keywords: Paulo Freire. Bernardo Kucinski. Testimony.

Resumen: Este artículo analiza el contexto actual de la persecución a la obra de Paulo Freire y reflexiona a través de una lectura crítica de "A visita do inspetor-geral", un cuento de Você vai voltar pra mim e outros contos, de Bernardo Kucinski (20I4), con se centran en la repetición de estrategias de censura y violencia contra ciertos sesgos políticos e ideológicos en la historia reciente de Brasil. Para apoyar la discusión, a nivel teórico, se realizó una encuesta bibliográfica de los autores Paul Ricoeur (2007) y Jeanne Marie Gagnebin (2006) sobre la memoria, por Márcio Seligmann-Silva (2003/2005) y Jaime Ginzburg (20I I) sobre literatura testimonial, y Bruno Botelho Costa (2016), Carlos Rodrigues Brandão (2006) y Moacir Gadotti (1996), entre otros, que abordan la obra de Paulo Freire. De esta manera, se observó que la narrativa de Kucinski actúa como testimonio del autoritarismo de la dictadura, por lo que su libro se convierte en un documento de memoria frente a los canales institucionales que operan el silenciamiento y manipulación del pasado.

Palabras-clave: Paulo Freire. Bernardo Kucinski. Testimonio.

\section{Introdução}

No ano de 2019, assumiu a presidência da república Jair Messias Bolsonaro, ex-militar e deputado que ganhou evidência midiática nos últimos anos em defesa de temas e de pautas conservadoras - como as que dizem respeito à manutenção das estruturas tradicionais da família patriarcal e da predominância dos princípios cristãos na organização da sociedade -, bem como pela oposição radical às políticas de defesa dos direitos humanos, observada, por exemplo, no discurso próarmamento da população e no ataque enérgico aos partidos, aos indivíduos e aos grupos que se declaram, ou são declarados, de esquerda. Estes, que frequentemente recebem, pelo presidente, seus aliados e seus eleitores, a etiqueta de "comunistas" e/ou "petistas", foram vinculados ao processo de demolição da imagem dos governos do Partido dos Trabalhadores (PT), tornando-se, por fim, os principais inimigos da ala política mais conservadora.

Nesse modus operandi, o governo vigente, desde o primeiro ano, tem sido fortemente marcado por ataques às áreas de humanidades, ocasionando embates ideológicos que na maior parte das vezes abandonam a mera divergência de ideias - com bases em orientações teóricas, críticas e/ou epistemológicas, por exemplo - e avançam para um processo de censura, de silenciamento e de eliminação de determinadas matrizes de pensamento.

Dentro dos campos do ensino e da educação, os ataques passaram a ser progressivos e recorrentes. Como amostra, destaca-se o discurso de posse do segundo Ministro da Educação do governo Bolsonaro, Abraham Weintraub, no dia 9 de abril de 2019, que afirmou: "se temos uma 
filosofia da educação tão boa, Paulo Freire é unanimidade, por que temos resultados tão ruins?"3. No dia 29 do mesmo mês, em entrevista, diante de projetos de lei elaborados para destituir o título de Patrono da Educação Brasileira de Paulo Freire, o atual presidente, por sua vez, asseverou: "quem sabe nós temos uma patrona da Educação e não mais um patrono muito chato, não precisa falar quem é, que nós temos até o momento. Ele vai ser mudado, estamos esperando alguém diferente"4.

Cerca de um mês depois, no dia 30 de maio, o deputado estadual Carlos Jordy (PSL-RJ) apresentou um projeto de lei para alterar o título de patrono da educação brasileira, propondo concedê-lo ao jesuíta São José de Anchieta ${ }^{5}$, canonizado pelo papa em 2014 . O projeto, entretanto, foi rechaçado pelo Santuário Nacional São José de Anchieta, que comparou Freire ao jesuíta por ambos darem prioridades aos pobres, com a justificativa de que "não podem aceitar que o legado de São José de Anchieta seja instrumentalizado para fins meramente ideológicos". O deputado Jordy retrucou os jesuítas afirmando que Freire é um "embuste”, um "comunista" e uma "farsa da Educação”.

Após um curto período, Paulo Freire voltou a ser pauta de notícias. No dia II do mês seguinte, o governador de Pernambuco, Paulo Câmara (PSB), no estado em que nasceu Freire, declarou no lançamento do Programa Criança Alfabetizada: "se vemos na educação o caminho da transformação é porque antes vieram pessoas guerreiras, comprometidas, como o pernambucano Paulo Freire. Não se iludam os que atacam e agridem a educação"7.

Já em $1^{\circ}$ de agosto de 2019, novamente o então Ministro da Educação, Abraham Weintraub, retornou ao assunto numa entrevista à Rádio Jovem Pan: "se o Paulo Freire fosse tão bom, ia ter mais um país usando o método dele. Coisa boa a gente copia e não tem nenhum país fora o Brasil que fala que o Paulo Freire é o modelo dele de educação. Onde tem?"8.

Numa via oposta, na ocasião de comemoração do Dia dos Professores, em 15 de outubro, o deputado estadual e ex-prefeito de Osasco Emidio de Souza (PT) publicou um vídeo em suas redes sociais se dirigindo ao PSL, ao presidente e aos seus apoiadores:

\footnotetext{
${ }^{3}$ Disponível em: https:/www.cartacapital.com.br/educacao/na-posse-weintraub-ataca-paulo-freire-e-faz-analiserasa-sobre-gastos/. Acesso em 22 ago. 2020.

4 Disponível em: https://oglobo.globo.com/sociedade/bolsonaro-diz-que-vai-mudar-patrono-da-educacaobrasileira-titulo-conferido-paulo-freire-23630439. Acesso em 22 ago. 2020.

5 Disponível em: <https://oglobo.globo.com/sociedade/educacao/deputado-quer-trocar-paulo-freire-poranchieta-como-patrono-da-educacao-mas-padres-sao-contra-23705925. Acesso em 22 ago. 2020.

${ }^{6}$ Idem.

7 Disponível em: https://blogs.nel0.uol.com.br/jamildo/2019/06/II/paulo-camara-cita-paulo-freire-e-soltaindiretas-para-bolsonaro/. Acesso em 22 ago. 2020.

${ }^{8}$ Disponível em: https://oglobo.globo.com/sociedade/e-ou-nao-feio-de-doer-escreve-abraham-weintraub-sobremural-de-paulo-freire-23848I 97. Acesso em 22 ago. 2020.
}

Olhar de professor, Ponta Grossa, v. 24, p. I-22, e-16757.014, 2021.

Disponível em <https://revistas2.uepg.br/index.php/olhardeprofessor> 
Memória e testemunho da violência contra o pensamento de Paulo Freire a partir de...

O desprezo que vocês têm por Paulo Freire, o mundo tem de reconhecimento. Ele ajudou a alfabetizar boa parte desse mundo. Ele fez a concepção de educação. Mas entendo. Vocês preferem muitas vezes homenagear Olavo de Carvalho, que nem amor pelo Brasil tem. É um nada. É um destruidor de biografias. Um demolidor de pessoas que trabalham corretamente. Eu prefiro Paulo Freire. Paulo Freire é um daqueles brasileiros que vão ficar na história para sempre?.

Esses eventos, entre tantos outros que poderiam ser aqui mencionados, não ocorreram por acaso ou de maneira desordenada. As disputas em torno das representações de Paulo Freire estão presentes tanto na esfera da política institucional quanto na sociedade civil, atingindo também um coletivo de indivíduos e de instituições que se tornaram alvos de perseguição e de violência.

\section{Ditadura e testemunho}

A estratégia de condenação de um determinado viés ideológico sob a justificativa de combate aos "verdadeiros inimigos da pátria", tomando como base o discurso ufanista, não se configura como uma novidade na história republicana do Brasil. Um procedimento muito semelhante foi utilizado para encerrar prematuramente o governo de João Goulart por meio de um golpe cujas justificativas se pautavam no combate à corrupção, à subversão e às ideologias comunistas. Causa estranhamento, portanto, que tais métodos de violência e de exclusão se repitam com tamanha semelhança, em especial se considerarmos o breve intervalo entre o fim da ditadura militar e os recentes ataques políticoideológicos e, além disso, por haver uma significativa parcela da população que atravessou ambos os períodos.

$\mathrm{Na}$ experiência ditatorial brasileira, observa-se uma tendência radical de apagamento de todo e qualquer rastro violento e antidemocrático praticado pelos aparelhos estatais de 1964 a 1985. Com o fim do regime sendo orquestrado pelos próprios militares, naquilo que se chamava de "transição lenta e gradual”, é notável que a lei $n^{\circ} 6.683$, de 28 de agosto de 1979, conhecida como Lei de Anistia, demarcou um corte abrupto sobre a memória desse período, em especial pelo ato de garantir anistia "ampla, geral e irrestrita" 10 , sem realizar um processo adequado de reconciliação da sociedade e de julgamento dos atos autoritários, levando a uma espécie de amnésia comandada - para usar o termo de Paul Ricoeur em A memória, a história, o esquecimento (RICOEUR, 2007, p. 462). Tal amnésia

\footnotetext{
${ }^{9}$ Disponível em: http://webdiario.com.br/noticia/27435/emidio-pede-mais-paulo-freire-e-menos-olavo-d. Acesso em 22 ago. 2020.

${ }^{10} \mathrm{Em}$ seu artigo $\mathrm{I}^{\circ}$, a lei concede anistia "a todos quantos, no período compreendido entre 02 de setembro de 1961 e 15 de agosto de 1979, cometeram crimes políticos ou conexo com estes, crimes eleitorais, aos que tiveram seus direitos políticos suspensos e aos servidores da Administração Direta e Indireta, de fundações vinculadas ao poder público, aos Servidores dos Poderes Legislativo e Judiciário, aos Militares e aos dirigentes e representantes sindicais, punidos com fundamento em Atos Institucionais e Complementares" (BRASIL, 20I9).
} 
representou o impedimento da condenação de responsáveis e envolvidos nos crimes, de maneira a favorecer a permanência, no campo político, de indivíduos e de estruturas diretamente comprometidos com as atrocidades cometidas pelo regime", viabilizando a continuidade da velha na nova ordem política (LEMOS, 2002, p. 297). Obstruindo aquilo que não deve ser lembrado pela sociedade, a anistia configura-se como uma memória impedida, uma vez que interrompe o registro no próprio ato de inscrição: "trata-se mesmo de um esquecimento jurídico limitado, embora de vasto alcance, na medida em que a cessação dos processos equivale a apagar a memória em sua expressão de atestação e a dizer que nada aconteceu" (RICOEUR, 2007, p. 462).

$\mathrm{Na}$ contramão desse apagamento, a literatura, assim como outras linguagens artísticas, se estabelece como um espaço de testemunho de experiências em cenários autoritários - em contextos democráticos ou ditatoriais - no qual se oportuniza um duplo movimento: de um lado, a vítima (e aqui entendemos como vítimas uma grande amplitude de indivíduos que sofreram violências físicas, psicológicas, simbólicas etc.) encontra uma possibilidade de efetivar seu relato, que com frequência é objeto de censuras e de silenciamentos nos mais diversos níveis - incluindo-se as interdições estatais, sociais e individuais (quando o próprio sujeito recalca a possibilidade de verbalizar a cena traumática); de outro lado, esse relato se transforma num importante rastro da experiência que de outra maneira talvez não chegasse ao conhecimento da sociedade. $O$ testemunho, portanto, se torna uma expressão individual de um evento coletivo, como um documento de memória daquilo que é negado à população saber.

Tradicionalmente, o que vem se chamando de literatura de testemunho se dedicava à voz daqueles que sobreviveram ao Holocausto/Shoah - a partir da noção de Zeugnis -, porém, ao longo dos anos de 1960, no contexto das ditaduras que emergiam na América Latina, especialmente nos países de língua espanhola, também ganhou atenção uma literatura de testimonio (SELIGMANN-SILVA, 2005). Márcio Seligmann-Silva (2003) demarca uma importante distinção com relação a esse sujeito que testemunha: aquele que vê como terceiro (testis), que pode testemunhar o que presenciou de maneira ocular, e aquele que sobreviveu (superstes) a uma experiência-limite, não apenas no sentido de ter escapado à morte, mas justamente por poder testemunhar a experiência de ter sobrevivido a tal evento.

No Brasil, observa-se uma maior atenção, nos estudos de literatura de testemunho, aos relatos de origem carcerária e da ditadura militar. O segundo tipo, que traz à luz facetas dos diversos modos de violência praticados ao longo do regime ditatorial, ora se aproxima do relato de experiência, de

\footnotetext{
11 'No Brasil, o 'espírito de reconciliação' que norteou este caráter recíproco contribuiu também para que fossem anistiados eticamente todos os que sustentaram a violenta ditadura militar. Muitos deles são, hoje, pilares da democracia brasileira, atuando em posições públicas destacadas” (LEMOS, 2002, p. 296).
}

Olhar de professor, Ponta Grossa, v. 24, p. I-22, e-16757.014, 2021.

Disponível em <https://revistas2.uepg.br/index.php/olhardeprofessor> 
Memória e testemunho da violência contra o pensamento de Paulo Freire a partir de...

maneira mais semelhante aos gêneros autobiográficos, ora recorre à ficção com maior liberdade, sem perder por isso a contundência. Nesse segundo caso se insere a literatura produzida por Bernardo Kucinski, que ganhou notoriedade no campo da literatura com seu romance K. - Relato de uma busca, publicado em 201l. A obra não impacta apenas pela qualidade e pela densidade da narrativa no tratamento de um tema duro como a busca de um pai por sua filha desaparecida durante o regime militar brasileiro, mas também por tocar na biografia do próprio autor, irmão de uma das vítimas de sequestro e tortura por órgãos de Estado.

O teor testemunhal (SELIGMANN-SILVA, 2003, p. 8) da narrativa de Kucinski é perceptível na medida em que o autor é uma vítima da ditadura. Embora não tenha sofrido tortura física como tantos outros, é fundamental lembrar que o autoritarismo engendra variadas formas de violência, como a censura, a repressão, o arrocho econômico e salarial, o terror psicológico, a perseguição política, a retirada de direitos, o exílio e, no caso do autor em pauta, também o sofrimento ocasionado pela prisão, pelo desaparecimento, pela tortura e pela morte de familiares e amigos. $O$ autor fez parte da imprensa alternativa durante a vigência da ditadura, exilado em Londres entre I97I e I 974 no contexto da perseguição política, e foi marcado pelo sequestro de sua irmã, Ana Rosa Kucinski, e de seu cunhado, Wilson Silva, em 1974. A confirmação da morte de ambos só se realizou anos mais tarde, incluídos entre as vítimas de incineração identificadas pelo ex-delegado Cláudio Guerra em seu depoimento em 2012 .

Se o romance $K$. - Relato de uma busca põe em evidência traços da biografia de Kucinski - ao coincidir parte da história narrada com a busca do autor por sua irmã sequestrada -, sua segunda obra de ficção, Você vai voltar pra mim e outros contos (2014), expõe, em vinte e oito breves contos, histórias que tocam em diversas nuances da ditadura militar e de suas consequências na vida da população, entre torturados, mortos e desaparecidos, assim como na de seus familiares e em sua comunidade de convívio.

O conto "A visita do inspetor geral" (KUCINSKI, 20I4, p. 6I-68), sobre o qual nos debruçaremos neste trabalho, situa a narrativa num cenário que acompanha de uma maneira aparentemente distanciada o golpe de 1964, porém com reverberações da atmosfera de violência, de silenciamento e de exclusão.

\section{O conto "a visita do inspetor geral"}

A história é dividida em cinco partes e tem seu título inspirado na peça "O inspetor geral" (1836), do russo Nikolai Gogol, "reconhecida por constituir-se como uma grande sátira social e política" (ROCHA, 2019, p. 25I). Lembremos, porém, que essa alusão deve nos remeter à temática 
que gira em torno da ditadura civil-militar brasileira, embora nem sempre datando exatamente entre 1964 e 1985, período reconhecido, respectivamente, pelo início e pelo encerramento do regime. Entende-se, assim, que,

Contos como "A visita do inspetor geral" recuperam e trazem flashes anunciadores da condição política, social e educacional experimentada pelos brasileiros entre 1950 e 1964 - as posturas combativas do então líder nacionalista e deputado estadual Leonel Brizola, a adoção do método freiriano de alfabetização e conscientização, o fechamento do Congresso Nacional (ROCHA, 2019, p. 233-234).

O conto se inicia com a subseção "O boato", que narra o anúncio da ida do inspetor-geral do Banco do Brasil à pequena cidade de Guariba - com apenas trinta mil habitantes, um cinema e uma pracinha central -, cujo objetivo sabiam apenas os personagens Melo, gerente aposentado da agência e que lá trabalhara durante a maior parte de sua vida, e seu filho Vicente. A voz que nos conta logo assume a primeira pessoa - "De que forma pai e filho ficaram sabendo é justamente o que vou contar" (20I4, p. 6I) -, isto é, alguém nos conta algo, porém de maneira anônima, uma vez que não nos é revelada sua identidade. $O$ anonimato do narrador associado ao cenário de cidade interiorana afastada dos grandes centros garante um determinado tom cômico à situação, numa espécie de história que se transmite oralmente e que comumente tende a ser nomeada como "causo", cujos exemplos abundam na literatura brasileira e na cultura popular.

O evento inesperado na pequena Guariba acaba adquirindo uma certa universalidade, como se, de alguma forma, pudesse ter ocorrido e se repetido em tantos outros municípios do país. Tal impressão se reforça pelos personagens que entram em cena: Antunes, dono do armazém e que herdara um sítio do tio-avô; Teixeira, dono da farmácia; Moisés, dono da barbearia; Terezinha Brandão, única funcionária mulher da agência. Todos eles são apresentados na primeira parte do conto como suspeitos do desenvolvimento do boato a respeito da chegada do Inspetor Geral - embora o narrador assegure que o boato não partira deles - e contribuem para a ambientação à maneira de um cenário corriqueiro em locais distanciados das regiões metropolitanas.

Na sequência da narrativa, na subseção "As aulas", algo começa a movimentar a cidade de Guariba: "havia um grupo dos onze que acompanhava pelo rádio os discursos de Leonel Brizola em favor das reformas de base. Falava-se também que alguns velhos comunistas reuniam-se de vez em quando não se sabia onde" (KUCINSKI, 20I4, p. 64). Nota-se, ainda antes do golpe civil-militar, uma atmosfera nebulosa em torno do comunismo e de tudo o que poderia ser a ele associado - como, no caso, os discursos de Leonel Brizola, as reformas de base e o método "considerado revolucionário", referindo-se às aulas que o filho do personagem Melo utilizava para a alfabetização de adultos por meio do Método Paulo Freire. O que no conto, apesar de não nomear expressamente Paulo Freire, encontramos, por exemplo, alusão a termos clássicos utilizados pelo educador em sua prática - por 
Memória e testemunho da violência contra o pensamento de Paulo Freire a partir de...

ser voltada a trabalhadores - como "ti-jo-lo". O método, que recorre a palavras do cotidiano do educando, aprimorado por Paulo Freire após a experiência em Angicos, foi implantando pelo governo de João Goulart em meados de 1963, mas retirado de vigor devido ao golpe de 1964.

Vicente dava aulas de alfabetização de adultos por um método do Ministério da Educação, considerado revolucionário. Todos os domingos, ele mais quatro amigos do colégio reuniam uns caboclos no salão paroquial para ensiná-los a ler e escrever. A cartilha que o Governo havia mandado usava palavras da vida das pessoas, como ti-jo-lo, ja-ne-la, ma-cha-do; assim ensinavam e conscientizavam ao mesmo tempo. Essa era a teoria (KUCINSKI, 20I4, p. 64).

No decorrer da narrativa, entretanto, ocorre a destituição do presidente da República em 1964, em subseção denominada "O golpe", na qual se relata a arbitrariedade das prisões e das perseguições políticas - fatos que persistiram por quase todo o período da ditadura - com base na eliminação de qualquer incidência de aspectos da ideologia comunista, o que se tornou um processo de caça a indivíduos que pudessem se envolver (ou serem acusados de estar envolvidos) com esse viés político-ideológico:

Sucedeu então o movimento militar que destituiu o presidente da República, fechou - Congresso Nacional e prendeu muita gente, entre os quais o ministro da Educação, que lançara o programa de alfabetização. Os jornais de São Paulo e de Araraquara denunciaram que tal método era uma invenção do comunismo internacional para subverter os brasileiros (KUCINSKI, 20I4, p. 64).

Se o movimento anticomunista ocasionava enormes danos nas grandes cidades, pode-se observar que na pequena Guariba - assim como, em geral, nas localidades fora dos polos de atuação militar - 0 assunto se tornara protocolar, sem apresentar um real significado para a população:

Em Guariba não havia guarnição do Exército e ninguém foi preso. $O$ delegado de polícia, o dr. Sérgio Costa, da família dos Costa lá de Jaboticabal, homem de índole mansa, deu um susto nos ferroviários e eles pararam de se reunir. Isso bastou. Nos comunistas não mexeu, porque nem sabia quem eles eram; até duvidava que existissem (KUCINSKI, 20I4, p. 64).

Ainda assim, o clima de tensão progredia a partir da impessoalidade dos boatos, um certo "conta-se que", como numa voz indeterminada, que ao mesmo tempo amedrontava e lançava incertezas sobre o futuro. Vicente foi informado por "um bancário" sobre as passagens do inspetorgeral em outras cidades, recebendo relatos sobre o aparelhamento de instituições como a polícia, a Igreja Católica e os colégios a fim de mapear os possíveis suspeitos de envolvimento com atividades subversivas: "Disse que, de São Paulo, o inspetor trouxera fichas, que conferira com o delegado de polícia, com o bispo e com diretores de colégios, e entrevistara os funcionários, um por um, para saber dos pais, dos amigos e o que eles pensavam da política” (KUCINSKI, 20I4, p. 65). 
Ao evidenciar um inimigo - os comunistas -, os militares promoviam o efeito de aterrorizar a população por meio de estratégias repressivas, em especial a censura, a prisão arbitrária, a tortura, o sequestro, o desaparecimento e a morte. Como dano colateral, muitas atividades foram encerradas, outras passaram a ser realizadas de maneira clandestina e, por fim, elevou-se um espírito de "entreguismo", de denúncia e de policiamento entre os próprios civis para se verem livres do inimigo (ou mesmo para não serem confundidos com ele):

De volta a Guariba, Vicente contou isso tudo ao pai. Combinaram manter segredo para não assustar o pessoal. Talvez 0 inspetor-geral só estivesse visitando as cidades maiores, e de Araraquara tivesse ido direto para Ribeirão Preto. Além disso, o velho Melo sabia que nenhum funcionário do banco estava metido em política; não era preciso prevenir ninguém. Quem estava metido em política era seu filho, isso sim, o Vicente, por causa desse programa de alfabetização de adultos, que agora todo mundo dizia que era subversivo (KUCINSKI, 20I4, p. 65).

No desenrolar do conto, o gerente da agência do Banco do Brasil recebe um comunicado, em sigilo, sobre a visita do inspetor-geral, sob o pretexto de "modernização", com o intuito de "adequar a agência às novas diretrizes de Segurança Nacional do Governo Federal” (KUCINSKI, 20I4, p. 66). Neste ponto, em conversa entre Dorival e Melo, seu antecessor, a narrativa recupera o tom irônico na medida em que os personagens ficam aliviados pelo fato de o inspetor-geral ser um antigo colega de trabalho. Para evitar maiores intromissões do inspetor, o ex-gerente trama detalhadamente uma rotina, que tende ao cômico, para distrair o inspetor, de modo que ele não alcance tempo hábil na cidade:

A chegada do inspetor numa sexta-feira inspirou o velho Melo. $O$ Geraldão vai desembarcar ao meio-dia, que é o horário do primeiro trem, vai se instalar, tirar o pó da viagem, antes da uma eu pego ele no Majestic pra gente almoçar com muita calma; não vai sobrar tempo pra ele fazer quase nada na sexta. No sábado, marcamos uma pescaria lá pros lados da represa da Promissão. Levamos muita pinga, pão e mortadela. Domingo o Costa vai pra Jaboticabal ver a família e só reabre a delegacia na segunda. $O$ Geraldão, de ressaca, vai se esticar na rede.

O problema é a segunda-feira, matutou Melo. Pensou, pensou. Sorte é que eu conheço as fraquezas do Geraldão. E decidiu. Chamou seu filho menor, o Reinaldo, e deu as ordens: vá ao sítio do tio Rocha e diga pra ele carnear um bezerro na outra segunda, que nós vamos lá mais uns amigos. Na volta, passa no Mathias e diz pra ele mais o Nazareno prepararem as violas pra um improviso. $O$ Geraldão é grande apreciador da viola de pinho, mais ainda do desafio. Mathias foi duas vezes campeão dos repentistas da Noroeste (KUCINSKI, 2014, p. 39).

Como resultado, narrado no "Epílogo", o inspetor-geral realizou apenas algumas entrevistas antes de partir de Guariba. Meses depois, transferiram a Terezinha, que era a única funcionária mulher do banco, o que gerou especulações sobre sua saída, se era por efeito da visita do inspetor-geral ou por rotina do banco. Ao fim, é Vicente, filho do ex-gerente do banco, que entra para vida clandestina. 
Memória e testemunho da violência contra o pensamento de Paulo Freire a partir de...

A cena denota a recorrente participação de jovens e estudantes nos movimentos de resistência ao regime militar, a despeito de serem filhos de pais conservadores e/ou alienados da política:

Sucedeu que ele mais dois monitores do programa de alfabetização, revoltados por tudo aquilo ter acabado, aderiram a uma turma da pesada de Bauru que queria fazer uma revolução. Não adiantou o velho Melo e sua mulher Letícia tentarem dissuadir o filho. Certa manhã Vicente meteu umas mudas de roupa na pequena maleta de cartão encerado, deu um abraço apertado no pai e na mãe e sumiu sem dizer para onde ia (KUCINSKI, 20I4, p. 68).

$\mathrm{Na}$ história, o autor opta pelo tom irônico para fazer críticas "às instâncias de poder e suas atitudes, e também aos diversificados segmentos sociais e como esses se portaram (e ainda se portam) frente aos fatos ocorridos" (ROCHA, 2019, p. 232). Na pequena Guariba se revela um microcosmo de como se instaurou e se assimilou o regime ditatorial em grande parte do Brasil, para além dos grandes centros urbanos, destacando-se "a chantagem, a bajulação, e estupidez burocrática, o preconceito, o 'emburrecimento' e a alienação” (ROCHA, 20I9, p. 232).

A obra de Paulo Freire tem atravessado esses processos de tensionamentos políticos tanto no contexto que envolve a narrativa de "A visita do inspetor-geral" quanto no atual período democrático da República, despontando com frequência como um dos principais nomes perseguidos por meio de ações autoritárias.

\section{Paulo Freire, educação e política}

Para compreender o percurso de Paulo Freire em sua atuação como educador dentro de um cenário de mudanças políticas, é necessário ter em vista a experiência que o conduziu a tais patamares de destaque. Formou-se em Direito pela atual Universidade Federal de Pernambuco em 1946, mas não exerceu a profissão, e no ano seguinte começou a trabalhar no departamento de Serviço Social no SESI, onde, mais tarde, tornou-se Diretor do Departamento de Educação e de Cultura em Pernambuco e depois na Superintendência.

No ano de 1960, Freire assumiu a direção da Divisão de Pesquisas no Movimento de Cultura Popular de Recife (MCP), da qual também foi um dos fundadores e onde agregou experiência para, no ano seguinte, dar início ao seu famoso método. Dois anos depois, tornou-se diretor do Serviço de Extensão Cultural (SEC) da Universidade do Recife. Devido à repercussão positiva de seu método de alfabetização, no ano subsequente, foi um dos membros do primeiro mandato do Conselho Estadual de Educação de Pernambuco, convidado a fazer parte da Comissão Nacional de Cultura Popular e ainda a assumir a coordenação do Plano Nacional de Alfabetização na passagem de 1963 para 1964.

Olhar de professor, Ponta Grossa, v. 24, p. I-22, e-16757.014, 2021.

Disponível em <https://revistas2.uepg.br/index.php/olhardeprofessor> 
Paulo Freire e seus companheiros começaram a ganhar espaço na área da política institucional graças a Aluísio Alves, governador do Rio Grande do Norte (196I-1966), que pretendia criar um programa de alfabetização em massa. Para realizar esse projeto num estado com poucos recursos, seu secretário da educação sugeriu convidar o educador Paulo Freire, "que anunciava ser capaz de alfabetizar em apenas 40 horas de aula" (LOBO, 20I3, p. 124).

O método desenvolvido por Freire e seus educandos-educadores foi fruto de uma primeira pequena experiência no Movimento Cultura Popular, em uma casa da periferia recifense, onde alfabetizaram 3 de 5 alfabetizandos, todos porteiros da capital. A partir dessa tentativa foram realizadas outras maiores em Angicos - a mais conhecida delas - e Mossoró, no Rio Grande do Norte, e em João Pessoa, na Paraíba, com a CEPLAR (Campanha de Educação Popular da Paraíba).

A metodologia criada a partir dessa prática e seus resultados impressionaram inclusive o governo federal. Mas em que consiste o "Método de alfabetização Paulo Freire"? É importante salientar, primeiramente, alguns pontos acerca do processo e dos pressupostos criados por Freire. Intitula-se aqui de processo, pois é algo muito além de um simples "método", que, por assim ser chamado, frequentemente sua compreensão pode ser simplificada e reduzida a apenas um conjunto de técnicas, por vezes até mecânicas, ligadas à aprendizagem da leitura e da escrita (FREIRE, 1996, p. 37). De acordo com Moacir Gadotti,

[a] rigor, não se poderia falar em "Método Paulo Freire", pois se trata muito mais de uma teoria do conhecimento e de uma filosofia da educação do que de um método de ensino. Mas, para sermos mais precisos, deveríamos chamar a esse "método" de "sistema", "filosofia" ou "teoria do conhecimento" (GADOTTI, 1996, p. 82).

Devido à popularização da epistemologia freiriana pelo termo "Método Paulo Freire", e por não ser este um tema central deste artigo, optou-se por manter a utilização dessa expressão - feitas as devidas ressalvas - para evitar uma possível redução da extensa filosofia do autor pernambucano.

Paulo Freire não criou meramente um método entre outros, sendo melhor ou não. Antes disso, ele acreditou em uma educação contra as outras (BRANDÃO, 2006, p. 7). Acreditou em uma educação que não fosse "bancária", na qual o educador disserta sobre conteúdos, de forma petrificada e estática, buscando sempre manter a dicotomia entre sujeito-narrador e objeto-ouvinte, com abordagem de uma realidade completamente distante da do educando, alheia a sua experiência existencial. Segundo o pernambucano, nessa distorcida visão educacional, o educador é sempre agente, sujeito, ator, que "enche" o educando desses muitos conteúdos, que são pedaços desconexos da realidade, separados de sua totalidade, na qual teriam significado.

Dentre os muitos retalhos de realidade transferidos por essa compreensão opressora educacional está o esvaziamento de significado da palavra, que a transforma em alienada e alienante, processo ao qual o Método Paulo Freire se contrapõe por não a perceber de acordo com sua mera 
Memória e testemunho da violência contra o pensamento de Paulo Freire a partir de...

"sonoridade", mas sim conforme a sua força transformadora (FREIRE, 20I4, p. 80). A metodologia freiriana de alfabetização concebe palavras não apenas como instrumentos de leitura da língua, mas como meios para leitura coletiva da realidade social. As palavras, então, devem ser escolhidas de acordo com alguns critérios: riqueza fonética, dificuldade fonética e densidade pragmática do sentido. Ou seja, é importante - para além da sonoridade - que as palavras contenham sentidos explícitos, carga afetiva e memória crítica: "Devem ser símbolos concretos da existência real das pessoas, como 'chuva', 'enxada' e 'lavoura' são para o lavrador; como 'favela', 'tijolo' e 'salário' são para o operário” (BRANDÃO, 2006, p. 15).

Para a educação bancária, a única função do educando é a de memorizar, gravar o conteúdo de forma mecânica: recebendo, guardando e arquivando os depósitos feitos, e não entendendo o que eles realmente significam. De acordo com esta visão educacional, o aluno bom é visto como o que se permite encher mais docilmente, e o bom educador, aquele que mais comunica e deposita conteúdos.

Segundo os pressupostos da educação bancária, "não há criatividade, não há transformação, não há saber" (FREIRE, 20I4, p. 8I), pois essa visão coloca o conhecimento como algo a ser doado pelos sábios para os que nada sabem, sempre do educador para o educando. Em conformidade com esse modelo educacional, é impossível a superação da contradição entre educador-educando, pois reflete a "sociedade opressora, sendo dimensão da 'cultura do silêncio', a 'educação' 'bancária' mantém e estimula a contradição" (FREIRE, 20I4, p. 82).

As pessoas são seres de adaptação, que se ajustam, o que vai contra os depósitos recebidos pelos educandos, não exercitando sua consciência crítica, a qual teria a capacidade de inseri-los no mundo com seu potencial transformador, colocando-os como sujeitos, atores de sua própria história. A imposição da passividade os leva a uma naturalização da opressão, conduzindo-os a uma adaptação ao mundo como ele é: opressor.

Acompanhando esse percurso, tal concepção reduz ou até anula $\circ$ potencial criativo dos educandos, levando-os para a esfera da ingenuidade ao invés da criticidade, servindo diretamente ao desejo dos opressores, em que "o fundamental não é o desnudamento do mundo, a sua transformação" (FREIRE, 20I4, p. 83). Seu real interesse se situa em "transformar a mentalidade dos oprimidos e não a situação que os oprime" (BEAUVOIR apud FREIRE, 20I4, p. 84), pois a educação bancária serve como prática da dominação, mantendo o educando na esfera da ingenuidade, o fazendo acomodar-se com a opressão - por mais que o educador não tenha essa pretensão. Porém, como as pessoas são seres que buscam e têm como vocação ontológica a sua humanização, na educação bancária encontramos elementos contraditórios que levam a sua superação. Os envolvidos podem perceber mais cedo ou mais tarde as "contradições em que a 'educação bancária' pretende mantê-los e engajarse na luta por sua libertação" (FREIRE, 20I4, p. 86). 
Cabe ao educador humanista, comprometido com a libertação, ser sujeito que "faz a hora e não esperar acontecer". Sua ação se identifica com a dos educandos, seguindo para a libertação de ambos: "do pensar autêntico e não no sentido da doação, da entrega do saber. Sua ação deve estar infundida da profunda crença nos homens. Crença no seu poder criador" (FREIRE, 20I4, p. 86).

Com o intuito de frisar a importância e a única possibilidade da libertação por meio da educação libertadora, Paulo Freire frisa em sua obra Pedagogia do Oprimido que é essencial para que o educador humanista seja coerente com sua prática educativa que ele - com a finalidade de atingir a libertação - não utilize de práticas "bancárias". Em suas palavras:

Nosso objetivo é chamar a atenção dos verdadeiros humanistas para o fato de que eles não podem, na busca da libertação, servir-se da concepção "bancária", sob pena de se contradizerem. Assim como também não pode esta concepção tornar-se legado da sociedade opressora à sociedade revolucionária (FREIRE, 20|4, p. 92-93).

A busca pela libertação humana terá êxito apenas se seu percurso e seu caminhar forem feitos de forma não alienante, permitindo a libertação autêntica. Essa verdadeira libertação é um processo, não pode ser concedida ou depositada. Não é alienante, mas sim práxis, "que implica a ação e a reflexão dos homens sobre o mundo para transformá-lo" (FREIRE, 20I4, p. 93).

$\mathrm{Na}$ concepção libertadora freiriana, na qual a ação que o educador adota tem como fim sua humanização e a dos educandos, com uma crença profunda nos homens e em seu poder criador, a contradição entre educando e educador é superada. $O$ educador durante o processo de aprendizado por meio do diálogo não apenas educa, mas também é educado, assim como o educando também educa o educador. É durante esse percurso que ambos se tornam sujeitos, já que

Agora ninguém educa ninguém, como tampouco ninguém se educa a si mesmo: os homens se educam em comunhão, mediatizados pelo mundo. Mediatizados pelos objetos cognoscíveis que, na prática "bancária", são possuídos pelo educador que os descreve ou os deposita nos educandos passivos (FREIRE, 20I4, p. 96).

Essa educação requer o constante desvelamento da realidade autenticamente reflexivo, assim sendo, o educador não deposita o conhecimento em meros receptores dóceis, pois estes "são agora investigadores críticos, em diálogo com o educador, investigador crítico também" (FREIRE, 20I4, p. 97).

Dito isso, o conhecido como Método de Alfabetização Paulo Freire convida o iletrado a se perceber como mulher ou como homem que vive e produz de determinada forma e em determinada sociedade. Ele desafia os sujeitos a saírem do conformismo e do "ser-menos", compreendendo que também são sujeitos criadores, que a posição que ocupam na sociedade não é estática e sequer um desígnio divino, mas decorre do "contexto econômico-político-ideológico da sociedade em que vivem" 
Memória e testemunho da violência contra o pensamento de Paulo Freire a partir de...

(FREIRE, 1996, p. 37). Essa percepção é o primeiro movimento necessário para que vejam a importância da alfabetização - e a partir de então já se encontram alfabetizados politicamente.

Na perspectiva de Carlos Brandão, "um dos pressupostos do método é a ideia de que ninguém educa ninguém e ninguém se educa sozinho. A educação, que deve ser um ato coletivo, solidário, um ato de amor, não pode ser imposta" (2006, p. 10). Ao evidenciar a não dicotomização entre o ato de ensinar e $\circ$ de aprender, $\circ$ autor frisa constantemente que tanto o educador aprende quanto $\circ$ educando ensina.

O método desenvolvido por Freire e seus companheiros deve iniciar-se envolvendo o máximo de pessoas da comunidade em que serão compostas as turmas para alfabetização. A experiência começa após o aceite das pessoas envolvidas, que juntas dos educadores irão construir o "conhecimento da realidade local: o lugar imediato onde as pessoas vivem e irão ser alfabetizadas" (BRANDÃO, 2006, p. II). Nessa primeira etapa da pesquisa, busca-se apreender o "universo vocabular"'2 da comunidade, compreendido como a investigação das palavras da cultura das pessoas do determinado local. É uma pesquisa simples em que se buscam os vocábulos mais utilizados pela comunidade: "todo ele é importante: palavras, frases, ditos, provérbios, modos peculiares de dizer, de versejar ou de cantar o mundo e traduzir a vida" (BRANDÃO, 2006, p. 12). E complementa: "são falas que, a seu modo, desvelam o mundo e contêm, para a pesquisa, os temas geradores falados através das palavras geradoras" (BRANDÃO, 2006, p. 12).

As palavras encontradas nesse procedimento são as "palavras geradoras", que não funcionam apenas como um instrumento de leitura da língua, mas também de uma leitura social da comunidade. O repertório de palavras utilizado pelo Método Paulo Freire, por nunca se colocar como neutro e entender que educação é política, parte de um critério de escolha, ao entender que alfabetizar não é um ato mecânico de repetir sem refletir. Na metodologia freiriana, "as palavras não são só um instrumento de leitura da língua; são também instrumentos de releitura coletiva da realidade social onde a língua existe, e existem os homens que a falam e as relações entre os homens" (BRANDÃO, 2006, p. 14). Boas palavras geradoras têm a capacidade de reunir grande riqueza fonética, conexão com a comunidade e potencial para conscientização (possibilidades de problematização a partir dela de acordo com as relações sócio-culturais da comunidade).

A etapa seguinte é uma forma de dupla leitura que se encarna na realidade vivenciada e da palavra escrita que a simboliza. Esta pode ser compreendida como uma dimensão maior, a dos "temas

\footnotetext{
${ }^{12}$ De acordo com Brandão (2006), Paulo Freire utiliza também outros termos parecidos para fazer alusão a essa etapa, como "levantamento do universo vocabular", "descoberta do universo vocabular", "pesquisa do universo vocabular" e "investigação do universo temático".
}

Olhar de professor, Ponta Grossa, v. 24, p. I-22, e-16757.014, 2021.

Disponível em <https://revistas2.uepg.br/index.php/olhardeprofessor> 
geradores", aplicando as palavras geradoras à vivência e à realidade do grupo, buscando evidenciar contradições.

Após a pesquisa realizada no cotidiano da comunidade, agora a caminhada segue organizada por meio de "círculos de cultura": um conceito criado para substituir a clássica sala de aula tradicional por um "círculo", com o auxílio do "animador de debates", o qual é o companheiro já alfabetizado, ao invés de um professor, e "de cultura", pois todos juntos aprenderão a partir dessa experiência. Por meio de tal organização, antes de trabalhar com a palavra escrita em si, o animador fomenta um debate e todos conversam sobre a questão que a palavra geradora suscita, sempre desafiando a um pensamento crítico. A partir de então, os materiais produzidos pela pesquisa, já reunidos, organizados e discutidos com as pessoas do local, são codificados e transformados por símbolos para serem utilizados: palavras geradoras, cartazes, fichas, desenhos, fonemas, fotos etc.

As primeiras experiências realizadas no Brasil e no Chile começavam com o pensar junto a partir de fichas de cultura, que são desenhos feitos em cartazes ou projetados, que em sequência provocavam debates por meio de ideias de situações cotidianas, como do conceito de cultura, para seguir a outros conceitos essenciais, como "trabalho" e "diálogo" (BRANDÃO, 2006, p. 21).

Foi durante a prática em Angicos, contando com a participação de lavradores, que houve as primeiras formas de "círculos de cultura", as quais alfabetizaram esses trabalhadores de dentro para fora, por meio do seu trabalho. Por seus excelentes resultados, o método foi levado ao Rio de Janeiro, a São Paulo e a Brasília.

A partir de diálogos estabelecidos nos círculos de cultura os alfabetizandos são convidados pelo coordenador a responder perguntas acerca de suas realidades, questionando e aprofundando suas leituras de mundo. $O$ debate provocado nessa prática tem como finalidade inspirar o educando a uma re-leitura crítica da realidade que possa trazer seu engajamento em práticas políticas em prol da transformação da sociedade.

Quê? Por quê? Como? Para quê? Por quem? Para quem? Contra quê? Contra quem? A favor de quem? A favor de quê? - são perguntas que provocam os alfabetizandos em torno da substantividade das coisas, da razão de ser delas, de suas finalidades, do modo como se fazem, etc. (FREIRE, 1996, p. 38).

A efetividade do método se encontra devido ao seu ponto de partida, que é a realidade do alfabetizando, seus conhecimentos e sua vida cotidiana. Paulo Freire tem a sensibilidade de respeitar e partir do senso comum para propor sua superação.

O "Método" obedece às normas metodológicas e lingüísticas, mas vai além delas, porque desafia o homem e a mulher que se alfabetizam a se apropriarem do código escrito e a se politizarem, tendo uma visão de totalidade da linguagem e do mundo (FREIRE, 1996, p. 39).

Olhar de professor, Ponta Grossa, v. 24, p. I-22, e-16757.014, 2021.

Disponível em <https://revistas2.uepg.br/index.php/olhardeprofessor> 
Memória e testemunho da violência contra o pensamento de Paulo Freire a partir de...

Seguindo a norma padrão da língua e a ultrapassando, incentivando a curiosidade do educando, o método apresenta uma perspectiva crítica de mundo. Não foca na mera repetição, no "bê-a-bá", portanto, a teoria do conhecimento ou a filosofia da educação proposta por Paulo Freire foge da reiteração alienada e alienante de fonemas e busca a leitura de mundo por meio da problematização. A companheira de Freire complementa:

O "Método" nega a mera repetição alienada e alienante de frases, palavras e sílabas,
ao propor aos alfabetizandos "ler o mundo" e "ler a palavra", leituras, aliás, como
enfatiza Freire, indissociáveis. Daí ter vindo se posicionando contra as cartilhas. Em
suma, o trabalho de Paulo Freire é mais do que um método que alfabetiza, é uma
ampla e profunda compreensão da educação que tem como cerne de suas
preocupações a sua natureza política (FREIRE, 1996, p. 40).

O método de Paulo Freire chegou a ter como resultado "300 trabalhadores alfabetizados em 45 dias" (WEFFORT apud FREIRE, 1980, p. 17), conquistando o apoio do Governo Federal, na época do presidente João Goulart, que decidiu implantá-lo em todo território nacional. Os governos populistas da época, como era o caso do governo Jango, se importavam muito com a alfabetização, pois ela era pré-requisito para votar, e como o Brasil da época possuía 50\% da população analfabeta, era uma adversidade que possuía extrema relevância política. Aos governantes havia um interesse, sobretudo, relativo ao aspecto eleitoral, pois o método elaborado por Paulo Freire possuía a capacidade de alfabetizar um significativo número de adultos num curto período de tempo, garantindo um aumento do colégio eleitoral. Quem estivesse na direção do projeto de alfabetização, portanto, teria também grande influência política no país.

No meio desse jogo de interesses, "em junho de 1963, Paulo Freire foi nomeado presidente da Comissão de Cultura Popular do MEC e, em março de 1964, o próprio Ministro da Educação o designou Coordenador do Programa Nacional de Alfabetização" (NOSELLA, 2007, p. I75-176). Assim, entre junho de 1963 e março de 1964 (antes do golpe civil-militar), "foram realizados cursos de formação de coordenadores na maior parte das Capitais dos Estados brasileiros" (SANDERS apud FREIRE, 1980, p. 17), pretendendo-se alcançar primeiro as zonas urbanas para depois seguir para as rurais.

Importante ressaltarmos aqui que o populismo dos anos de 1960 no Brasil não foi apenas manipulação das massas, pois possuía também objetivos delineados em prol da independência nacional, em busca de uma sociedade mais igualitária e a defesa de direitos trabalhistas ${ }^{13}$. Forças ligadas à esquerda, intelectuais, políticos, estudantes e até movimentos sociais revolucionários tinham apoio nesse governo. Seguindo essa perspectiva política, a alfabetização de adultos não era apenas ligada ao

\footnotetext{
${ }^{13}$ Para mais informações, ver Francisco C. Weffort, "O populismo na política brasileira” (I978), no qual o autor defende que existem vários sentidos políticos e culturais do populismo no Brasil.
} 
número de votos, "mas, sobretudo, de natureza político-ideológica e cultural em favor dos oprimidos" (NOSELLA, 2007, p. 177).

Isso pode ser verificado no seguinte discurso proferido pelo presidente João Goulart, em I963, após a alfabetização da primeira turma em Angicos:

\begin{abstract}
Desejo que centenas destes cursos se espalhem pelo território brasileiro, para que, num futuro próximo, todos os nossos patrícios, todas as nossas patrícias e, especialmente, os que estão mais à margem da civilização, aqueles que vivem mais longe e são mais pobres, possam também receber este benefício mínimo, que é o direito, também, de participar e de se integrar na vida da Nação [...]. Este povo, quando tomar conhecimento das letras e depois delas das leis da nossa Pátria, há de se integrar ao País, na luta extraordinária que todos juntos devemos realizar pela emancipação econômica da nossa Pátria, para que não se assista espetáculos de tanto contraste social e de tanta miséria em tantas regiões da nossa Pátria (GOULART apud GADOTTI, 20I4, p. 56-57).
\end{abstract}

De acordo com o que vem sendo discutido neste artigo, percebe-se que a alfabetização possui uma conexão direta com a política, assim como a proposta educacional de Freire. Sua concepção foi capaz de unir "uma agenda educacional (como no caso da alfabetização) e uma luta política pautada a partir da voz do povo, em que o questionamento e a denúncia desses problemas pelo próprio povo fossem o esteio de sua mobilização e organização" (COSTA, 2016, p. 96).

Ao relacionar um posicionamento político à questão da alfabetização, mas não uma alfabetização por meio da repetição, e sim do pensar crítico, a pedagogia freiriana tem a capacidade de mobilizar o povo por colocar-se diretamente como um instrumento em prol da organização política, unindo toda essa esfera a uma maior em busca da liberdade e da transformação. Segundo Brandão, Freire,

Pensa e repensa o homem, a história, o trabalho, a cultura, a educação e mais o fio que amarra e puxa tudo isso: a liberdade. [...] Ele imaginou criar uma ferramenta que ajudasse o homem a começar pelo começo; por um jeito mais humano de ensinaraprender a ler-escrever (BRANDÃO, 2006, p. 7).

A alfabetização, para Paulo Freire, é um ato político. Para ler não devemos esquecer o mundo em que estamos inseridos, assim sendo, seu método pontua a importância da "leitura de mundo", pois a alfabetização, como a educação e tudo que a envolve, deve servir para libertar o homem, não apenas para ensiná-lo e jamais para domesticá-lo.

Com o advento do golpe de 1964, entretanto, o esforço educativo de Freire e de seus companheiros por uma educação e cultura popular foi interrompido, levando o pernambucano à prisão por 75 dias e a alguns interrogatórios, o que culminou em ser considerado "subversivo internacional". Apesar da perseguição, Freire foi capaz de escapar graças ao refúgio na Embaixada da Bolívia e seguiu para o exílio. 
Memória e testemunho da violência contra o pensamento de Paulo Freire a partir de...

Mesmo com muitas ressalvas do educador em deixar o Brasil, foi um ato necessário devido ao cenário político e econômico do país no início dos anos de 1960, momento no qual dominavam governos populistas (desde 1930) e o capitalismo internacional pressionava por uma expansão industrial e econômica. Mas o jogo populista de massas passou a se radicalizar a ponto de trazer ameaças à dominação realizada pelo capital internacional na economia brasileira, tornando-se insustentável para a classe dominante sentir abaladas suas estruturas de dominação. A solução adotada pelo empresariado nacional, com o apoio do capital internacional, veio na forma do golpe civil-militar de 1964 (I964-1985), desencadeado no dia 3 I de março e que culminou em I de abril, destituindo o governo de João Goulart com força militar e suporte de segmentos médios da sociedade, aliados à propaganda anticomunista.

Sustentado por uma campanha de censura ideológica ao comunismo, o golpe implementou a expansão de outra ideologia educacional, que fazia ataques à base da cultura brasileira, colocando em seu lugar uma concepção tecnicista da educação, voltada para o crescimento econômico, pauta orientada pelo capital internacional.

Assim, este Estado autoritário e intervencionista organizou-se de forma a incrementar diferentes mecanismos de repressão que atingiram, entre outros, aqueles que estavam envolvidos com uma proposta educativa que veiculasse qualquer orientação ideológica diferente à população trabalhadora (CARVALHO, 20I2, p. 42).

Durante a ditadura no Brasil, iniciou-se um período em que a "ideologia do nacionalismo desenvolvimentista foi substituída pela doutrina da interdependência” (SAVIANI, 20II, p. 364). Logo, a educação foi ajustada ao modelo econômico do capitalismo de mercado associado dependente, que possuía como plano de fundo a teoria do capital humano (formulada inicialmente por Theodore Schultz), "com os corolários do 'máximo resultado com o mínimo de dispêndio' e 'não duplicação de meios para fins idênticos"” (SAVIANI, 20II, p. 365).

Como a proposta educativa de Paulo Freire acredita que a educação e a política são indissociáveis, propondo, a partir da educação, uma transformação radical da sociedade por meio de uma consciência crítica, logo após o golpe de 1964, Freire, que ocupava o cargo de Coordenador do Programa Nacional de Alfabetização, e outros movimentos de intelectuais e artistas foram perseguidos "pois representavam a ideologia de esquerda, preocupada com a formação cultural da classe trabalhadora, e foram combatidos a qualquer preço, sob a justificativa de se constituírem em um ensino subversivo" (CARVALHO, 2012, p. 43).

A educação problematizadora freiriana vai diretamente contra a proposta do governo golpista de 1964, assim, duas semanas após a tomada do poder pelos militares, no dia 14 de abril, o Programa Nacional de Alfabetização foi extinto e, dois dias depois, Paulo Freire foi preso. Durante seu exílio no Chile, Freire se engajou na luta pela educação popular e seu método teve reconhecimento mundial 
graças ao apoio do presidente Eduardo Frei. O educador pôde desenvolver e aplicar seu método, o qual foi implantado nos programas de alfabetização do governo, trazendo excelentes resultados e reconhecimento.

Em dois anos o programa chileno atraiu a atenção internacional, e o Chile recebeu da UNESCO uma distinção que o aponta como uma das cinco nações que melhor superam o problema do analfabetismo. Em 1968, ○ Escritório calcula que terá aproximadamente 100.000 alunos e 2.000 coordenadores (SANDERS apud FREIRE, 1980, p. 23).

A percepção adquirida no processo chileno em contraposição à experiência brasileira serviu de inspiração para sua obra mais conhecida, Pedagogia do Oprimido, e outras mais, como Educação como Prática da Liberdade e Ação Cultural para a Liberdade. Paulo Freire seguiu do Chile rumo aos EUA, onde passou um período lecionando na Universidade de Harvard, mas logo seguiu para Genebra, em trabalho com o Conselho Mundial de Igrejas, na coordenação e na elaboração projetos educacionais em diversos países, principalmente no continente africano, o que proporcionou o enriquecimento de sua visão de libertação devido ao processo de descolonização que acontecia em algumas nações com as quais teve contato.

Depois de 16 anos como exilado, o retorno de Freire o levou a reaprender a realidade brasileira (MELO, 1982, p. 9). Foi convidado pela PUC de São Paulo e pela UNICAMP. Mas sua atuação não foi limitada à vida acadêmica, pois trabalhou com muitos grupos e equipes na periferia de São Paulo e Campinas, às vezes nas CEBs (Comunidades Eclesiásticas de Base) e até com estudantes de outras regiões, que o procuravam.

\section{Considerações finais}

Ao suscitarmos neste artigo o debate em torno do golpe de 1964, da ditadura militar e do legado de Paulo Freire a partir da leitura do conto "A visita do inspetor-geral”, de Bernardo Kucinski, percebe-se que a literatura estabelece um espaço de reflexão sobre a articulação do princípio do processo de censura, de repressão e de exclusão do pensamento de Paulo Freire em meados da década de 1960 e as perseguições ideológicas percebidas na segunda década do século XXI.

O relato que se aborda na obra de Kucinski, como testemunho de quem sobreviveu ao terror da ditadura, se torna um importante rastro daquilo que é impedido de ser conhecido pela população, configurando-se como um exercício de memória, mas não apenas no sentido de rememorar os atos autoritários do regime militar, e sim como uma tarefa ética de preservar o passado do desaparecimento (GAGNEBIN, 2006, p. 97). O autor assume uma "postura contestatória e corajosa frente a um passado tão presentificado em atos políticos e sociais ainda hoje recorrentes" (ROCHA, 2019, p. 232). 
Memória e testemunho da violência contra o pensamento de Paulo Freire a partir de...

Em seu testemunho, Kucinski põe em evidência a terrível faceta da perseguição política com base no discurso anticomunista. Em "A visita do inspetor-geral", como se observa, torna-se explícito que a própria população assimilava com dificuldades o discurso que instava condenar qualquer indivíduo ou instituição que fosse vinculado a um viés ideológico comunista. Ao garantir ao conto um tom irônico - por vezes cômico - e caracterizando o cenário e as personagens de maneira tão facilmente reconhecíveis em outras localidades por todo o Brasil, o autor dá a ver um caráter de improvisação e de amadorismo na implantação e na expansão das políticas do governo militar. Contudo, como sabemos, a violência e o autoritarismo escalaram ano a ano durante a ditadura, com seu período mais devastador e cruel sendo demarcado pelo Ato Institucional n. 5, de 1968, que retirou uma série de direitos da população.

Assim como Bernardo Kucinski, Paulo Freire não foi vítima de tortura, mas sofreu a violência do acossamento político e do exílio. No atual cenário brasileiro, são observáveis traços semelhantes de ações autoritárias que resultam em variados tipos de violência contra pessoas com base em suas orientações ideológicas. O legado de Paulo Freire se torna novamente um alvo da perseguição política violenta e das tentativas de eliminação de sua presença no contexto educacional - o que denota, ao mesmo tempo, que sua obra permanece confrontando as perspectivas mais conservadoras da política e da educação.

Diante deste estudo, é notório perceber que se arquiteta paulatinamente nos últimos anos uma nova onda de repressão a vieses políticos e ideológicos com base na violência e no autoritarismo. A literatura de testemunho, entretanto, compõe o campo de resistência na "perspectiva para a compreensão do passado a partir dos excluídos" (GINZBURG, 20II, p. 24). Sendo assim, ela elabora uma via alternativa de acesso à memória institucionalmente impedida - o que por si só também configura um ato de violência, na medida em que desampara a possibilidade do julgamento e da condenação dos algozes.

Espera-se que as discussões empreendidas neste trabalho contribuam para o debate sobre como a literatura pode se tornar um documento de memória na contramão das vias institucionalizas que operam o silenciamento e a manipulação do passado. A repetição de um ato de violência não significa que ele ocorrerá exatamente da mesma forma, pois os governos autoritários encontram novas estratégias a fim de garantir suas estruturas de poder. Recuperar a memória censurada é um movimento fundamental para romper o ciclo que mantém periodicamente os agentes da violência nos postos de comando do país. 


\section{Referências}

BRANDÃO, C. R. O que é método Paulo Freire. São Paulo: Brasiliense, 2006.

BRASIL. Lei $n^{\circ} 6.683$, de 28 de agosto de 1979. Concede anistia e dá outras providências. Disponível em: <http://www.planalto.gov.br/ccivil_03/leis/L6683.htm>. Acesso em: 30 out. 2019.

CARVALHO, M. A. B. Paulo Freire e o exílio no Chile: uma contribuição recíproca para uma visão de mundo. In: GADOTTI, M.; ABRÃO, P. (Org.). Paulo Freire anistiado político brasileiro. São Paulo: Instituto Paulo Freire/Comissão da Anistia, Ministério da Justiça, 20 I2. p. 4I-54.

COSTA, B. B. Paulo Freire: educador-pensador da libertação. Pro-Posições, v. 27, n. I (79), p. 93II0, jan./abr. 2016.

FREIRE, A. M. A.. A voz da esposa: A trajetória de Paulo Freire. In: GADOTTI, M. (Org.). Paulo Freire: uma biobibliografia. São Paulo: Cortez/ Instituto Paulo Freire. 1996. P. 27-68.

FREIRE, P. Conscientização: teoria e prática da libertação: uma introdução ao pensamento de Paulo Freire. São Paulo: Editora Moraes, 1980.

FREIRE, P. Pedagogia do Oprimido. Rio de Janeiro: Editora Paz e Terra, 2014.

GADOTTI, M. Alfabetizar e Politizar. Angicos, 50 anos depois. Foro de Educación, v. I2, n. 16, p. $5 \mathrm{I}-70,20 \mathrm{I} 4$.

GADOTTI, M. A voz do biógrafo brasileiro: A prática à altura do sonho. In: GADOTTI, M. (Org.). Paulo Freire: Uma bibliografia. São Paulo: Cortez/ Instituto Paulo Freire, 1996. p. 69-II6.

GAGNEBIN, J. M. Lembrar escrever esquecer. São Paulo: Ed. 34, 2006.

GINZBURG, J. Linguagem e trauma na escrita do testemunho. In: SALGUEIRO, Wilbert (Org.). 0 testemunho na literatura: representações de genocídios, ditaduras e outras violências. Vitória: EDUFES, 2011. p. 19-29.

KUCINSKI, B. K. - Relato de uma busca. São Paulo: Cosac Naify, 201 I.

KUCINSKI, B. Você vai voltar pra mim e outros contos. São Paulo: Cosac Naify, 2014.

LEMOS, R. Anistia e crise política no Brasil pós-1964. Topoi, Rio de Janeiro, v. 3, n. 5, p. 287-3 I3, dez. 2002.

LOBO, L. A experiência de Angicos. Em aberto, Brasília, v. 26, n. 90, p. 123-129, jul./dez. 2013.

MELO, J. M. de. El exilio de Paulo Freire. Chasqui, n. 2, p. 6-I2, 1982.

NOSELLA, P. Paulo Freire: orgulho dos educadores brasileiros. EccoS, São Paulo, v. 9, n. I, p. I73I82, jan./jun. 2007.

RICOEUR, P. A memória, a história, o esquecimento. Campinas, SP: Editora da Unicamp, 2007.

Olhar de professor, Ponta Grossa, v. 24, p. I-22, e-16757.014, 2021.

Disponível em <https://revistas2.uepg.br/index.php/olhardeprofessor> 
ROCHA, F. R. da. Representações literárias dos "anos de chumbo" em Batismo de Sangue e Você vai voltar pra mim. 2019. Tese (Doutorado em Letras) - Universidade Presbiteriana Mackenzie, São Paulo, 2019. Disponível em:

http://tede.mackenzie.br/jspui/bitstream/tede/4 I 6/5/Fernanda\%20Reis\%20da\%20Rocha.pdf. Acesso em: 0I mar. 202I.

SAVIANI, D. Educação na ruptura política para a continuidade socioeconômica. In: SAVIANI, D. História das Ideias Pedagógicas no Brasil. 3. ed. rev. Campinas, SP: Autores Associados, $20 \mathrm{II}$. p. 349-366.

SELIGMANN-SILVA, M. História, memória, literatura. Campinas: Ed. Unicamp, 2003.

SELIGMANN-SILVA, M. O local da diferença: ensaios sobre memória, arte, literatura e tradução. São Paulo: Ed. 34, 2005.

Recebido em: 28 de agosto de 2020.

Versão corrigida recebida em: 07 de dezembro de 2020.

Aceito em: 07 de dezembro de 2020.

Publicado online em: 05 de março de 2021 . 